\title{
PENGARUH KEBIJAKAN TREATMENT KARYAWAN TERHADAP EFEKTIVITAS PENGENDALIAN INTERNAL DAN KUALITAS LAPORAN KEUANGAN SEKTOR PUBLIK
}

\author{
Endang Tri Pratiwi \\ Program Studi Akuntansi, Fakultas Ekonomi \\ Universitas Muhammadiyah Buton, Baubau, Indonesia \\ Email: endangtripratiwi12@gmail.com
}

\begin{abstract}
ABSTRAK
Penelitian ini bertujuan untuk mendeskripsikan bukti empiris terkait pengaruh kebijakan treatment karyawanterhadap kualitas laporan keuangan yang dimediasi oleh efektivitas pengendalian internal.Populasi adalah pejabat penatausahaan keuangan dan aset serta bendahara yang terdapat pada Satuan Kerja Perangkat Daerah (SKPD) se-Pemkot Baubau. Penentuan besarnya sampel menggunakan formula Slovin dengan jumlah sebesar 102 responden. Metode pengumpulan data dilakukan melalui penyebaran kuesioner.Teknik analisis data menggunakan path analysis dengan bantuan software SPSS versi 20. Hasil penelitian menunjukkan kebijakan treatment karyawan berpengaruh positif terhadap efektivitas pengendalian internal Pemerintah Kota Baubau.Namun, kebijakan treatment karyawan tidak berpengaruh terhadap kualitas laporan keuangan Pemerintah Kota Baubau.Penelitian ini membuktikan adanya efek mediasi penuh oleh efektivitas pengendalian internal pada pengaruh kebijakan treatment karyawan terhadap kualitas laporan keuangan.
\end{abstract}

Kata Kunci: Kebijakan Treatment Karyawan, Efektivitas, Pengendalian Internal, Kualitas Laporan Keuangan

\begin{abstract}
This study aims to describe empirical evidence about the effect of employee treatment policies on the quality of financial statements that are mediated by the effectiveness of internal controls. The population was officials of financial and asset administration and treasurer in the Regional Work Units (SKPD) of the Baubau City Government. Determination of the size of the sample using Slovin formula with a total of 102 respondents. The method of data collection is done through questionnaires. The data analysis technique used path analysis with SPSS version 20 software. The results showed that the employee's treatment policy had a positive effect on the effectiveness of the internal control of the Baubau City Government. However, the employee's treatment policy does not affect the quality of the Baubau City Government financial report. This study proves the existence of a full mediating effect by the effectiveness of internal controls on the effect of employee's treatment policies towards the quality of financial statements.
\end{abstract}

Keywords: Employee's Treatment Policy, Effectiveness of Internal Controls, Quality of Financial Statements 


\section{PENDAHULUAN}

Reformasi pada bidang keuangan negara melalui serangkaian regulasi telah dilakukan sejak kebijakan desentralisasi fiskal diberlakukan dalam rangka meningkatkan kualitas pengelolaan keuangan negara/daerah.Pengelolaan keuangan yang berkualitas dapat diukur dengan banyaknya unit kerja pemerintah yang mendapatkan opini Wajar Tanpa Pengecualian (WTP). Hasil audit BPK menunjukkan bahwa masih banyak unit kerja pemerintah yang belum mendapatkan opini Wajar Tanpa Pengecualian (WTP), dikarenakan lemah atau tidak efektifnya sistem pengendalian internal.

Penerapan sistem pengendalian internal yang berkualitas dan efektif menjadi sangat penting.Kondisi ini didukung masih dominannya laporan hasil pemeriksaan BPK yang menunjukkan kelemahan sistem pengendalian internal di lingkungan pemerintah daerah. Kelemahan sistem pengendalian internal tersebut mengalami peningkatan yang signifikan. Hal ini sesuai data hasil pemeriksaan tahun 2013 menunjukkan kelemahan struktur pengendalian internal sebanyak 526 kasus sedangkan tahun 2014 menunjukkan kelemahan struktur pengendalian internal sebanyak 1.314 kasus. Oleh karena itu, diperlukan keberadaan sistem pengendalian internal yang efektif untuk mencegah tindakan kecurangan/penyimpangan yang disebabkan sistem pengendalian internal yang lemah tersebut.

Penerapan pengendalian internal yang buruk serta adanya kelemahan dan penyelewengan pada pengendalian internal merupakan dua faktor utama yang menyebabkan terjadinya kecurangan. Di New Zealand, responden yang mengalami kecurangan dari karyawannya pada tahun 2008 sebanyak 31\% disebabkan pengendalian internal yang buruk, dan pada tahun 2012 meningkat menjadi 35\%. Selain itu, hasil survei lainnya menunjukkan cara utama untuk mendeteksi kecurangan yang sudah terjadi adalah melalui sistem pengendalian internal. Sebaliknya, sebanyak $49 \%$ responden di Negara Australia dan New Zealand telah mendeteksi kecurangan yang dilakukan oleh karyawannya dengan mengimplementasikan pengendalian internal yang kuat [1].

Permasalahan-permasalahan dalam penerapan Sistem Pengendalian Internal Pemerintah (SPIP) yang menyebabkan kualitas SPIP menjadi buruk, khususnya lingkungan pemerintah daerah yakni: (a) Sikap pimpinan yang kurang mendukung 
sehingga belum memberikan kontribusi secara optimal dan kurangnya peran kelembagaan yang berkomitmen terhadap upaya sistem pengendalian internal sehingga tingkat keberhasilan pelaksanaan SPIP sangat rendah dan rentan akan timbulnya kecenderungan penyimpangan; (b) Peran inspektorat daerah dalam melakukan penugasan audit belum begitu baik dan sesuai standar audit pada tiap-tiap SKPD sehingga mengakibatkan hasil audit pun menjadi kurang efektif; (c) Rekomendasi yang diberikan auditor intern terkait SPI tidak ditindaklanjuti secara cepat dan tepat oleh SKPD sehingga kondisi sistem pengendalian intern belum baik, padahal rekomendasi itu diperlukan untuk memantau dan menilai efektivitas dalam mengelola kegiatan organisasi supaya mencapai tujuan yang telah ditetapkan; (d) Banyaknya aparatur pegawai pada SKPD yang kurang peduli maupun kurang kompeten dalam penerapan SPIP sehingga menyebabkan timbulnya ketidakjelasan ataupun tumpang tindih dalam pembagian tugas maupun pemisahan wewenang; (e) Tata kelola pemerintahan yang belum optimal dan perlu penataan ulang proses kegiatan/program dalam melibatkan stakeholder (pemangku kepentingan di lingkungan birokrasimaupun masyarakat), diantaranya pemerintah daerah belum mewujudkan akuntabilitas dan transparansi pelaporan sehingga pemerintah daerah belum menjadi subyek pemberi informasi dalam rangka pemenuhan hak-hak publik, yaitu hak untuk diberi informasi dan penjelasan, didengar aspirasinya melalui partisipasi, serta dilayani secara baik [2].

Faktor yang mempengaruhi kualitas sistem pengendalian internal, di antaranya kompetensi sumber daya manusia [2].Pengendalian internal yang telah dirancang dan disusun dengan baik, tidak dapat dikatakan sepenuhnya optimal karena keberhasilannya perlu ditunjang dari kompetensi, integritas dan nilai etis sumber daya manusia dalam pelaksanaannya. Tingkat pendidikan karyawan berpengaruh positif terhadap kualitas sistem pengendalian internal [3]. Hasil penelitian terdahulu menyatakan bahwa perusahaan yang berpartisipasi dalam restrukturisasi kemungkinan menghadapi kegagalan pengendalian internal yang lebih besar karena masalah personil terkait dengan pembagian tugas, staf yang tidak memadai dan masalah pengawasan [4]. Penelitian lainnya menemukan bahwa perusahaan yang lebih kecil dan lebih muda cenderung mengungkapkan masalah kepegawaian dari perusahaan lain yang mengungkapkan kelemahan material. Perusahaan-perusahaan tersebut juga cenderung menjadi paling lemah secara finansial, dengan kerugian dan risiko kebangkrutan 
tertinggi. Keterbatasan sumber daya kemungkinan menghambat kemampuan perusahaan tersebut untuk staf dalam operasi yang memadai dengan personil kompeten [5]. Selain itu, Penelitian menemukan bahwa studi empiris dari system perbankan China menemukan bahwa komitmen untuk kompetensi, struktur organisasi, perilak umanajemen, sistem informasi, dan tugas wewenang serta tanggung jawab terbukti menjadi variabel pengendalian internal yang paling berpengaruh. Dengan demikian, jika kompetensi sumber daya manusia di suatu pemerintah daerah mengenai sistem pengendalian internal cukup baik maka dapat menerapkan kualitas pengendalian internal yang baik [6].

Konsisten dengan teori modal manusia dalam tata kelola organisasi, penelitian ini memfokuskan pada keefektifan pengendalian internal untuk mengevaluasi pentingnya human capital dalam praktek akuntansi. Kurangnya kualifikasi staf akuntansi dengan keahlian teknis, berkaitan dengan prinsip-prinsip akuntansi berterima umum, menyebabkan pengendalian internal tidak efektif. [7].

Pemilihan lokasi penelitian dikarenakan Pemerintah Kota Baubau merupakan salah satu pemerintah daerah di Provinsi Sulawesi Tenggara yang memperoleh opini WTP DPP pada tahun 2014-2016, dan opini WTP pada tahun 2015. Peningkatan opini tersebut menarik untuk dikaji disebabkan pelaporan keuangan pada tahun 2014 dan 2015 menggunakan basis keuangan yang berbeda, yaitu pada tahun 2014 laporan keuangan pemerintah daerah berbasis cash towards accrual sedangkan pada tahun 2015 laporan keuangan pemerintah daerah diwajibkan menggunakan basis akrual penuh sebagaimana yang diamanatkan dalam PP Nomor 71 Tahun 2010 [8]. Dengan demikian, penelitian ini bertujuan untuk mendeskripsikan bukti empiris terkait pengaruh kebijakan treatment karyawan terhadap kualitas laporan keuangan yang dimediasi oleh efektivitas pengendalian internal.

\section{METODE PENELITIAN}

Penelitian ini merupakan penelitian kausalitas, yang bertujuan untuk menganalisis hubungan dan pengaruh (sebab-akibat) dari dua atau lebih fenomena melalui pengujian hipotesis [9]. Populasi yang digunakan dalam penelitian ini adalah pejabat penatausahaan keuangan dan aset serta bendahara yang terdapat pada Satuan Kerja Perangkat Daerah (SKPD) se-Pemkot Baubau, sehingga jumlah populasi dalam penelitian ini adalah 136 responden. Teknik pengambilan sampel yang digunakan 
adalah purposive sampling, yaitu memilih sampel dengan kriteria bahwa sampel terlibat setidaknya 2 tahun dalam pelaporan keuangan di masing-masing SKPD. Penentuan besarnya sampel dalam penyebaran instrumen adalah dengan menggunakan formula Slovin [10] sehingga diperoleh sampel sebesar 102 orang.

Data primer dalam penelitian ini menggunakan kuesioner untuk memperoleh jawaban responden [10]. mendefinisikan kuesioner sebagai teknik pengumpulan data yang dilakukan dengan cara memberi seperangkat pertanyaan atau pernyataan tertulis dalam bentuk tertutup (pilihan jawaban sudah disediakan) maupun terbuka (tidak disediakan pilihan jawaban) kepada responden untuk dijawabnya.

Bentuk kuesioner yang digunakan oleh peneliti adalah kuesioner tertutup.Penelitian ini terdiri atas tiga variabel, yakni Kualitas Laporan Keuangan (KLK), Kebijakan Treatment Karyawan (KTK), dan Efektivitas Pengendalian Intern (EPI). Teknik analisis data yang digunakan dalam penelitian ini terdiri dari statistik deskriptif dan uji kualitas data. Teknik analisis data dalam penelitian ini menggunakan analisis jalur (path analysis) dengan bantuan software SPSS versi 20.

\section{HASIL DAN PEMBAHASAN}

\section{Hasil Penelitian}

\section{Tingkat Pengembalian Kuesioner}

Pengumpulan data dalam penelitian ini dilakukan dengan menyebarkan kuesioner kepada 102 responden. Kuesioner yang kembali berjumlah 57 dan beberapa kuesioner yang kembali tidak semua dapat diolah karena kuesioner tidak diisi dengan lengkap. Beberapa hal yang juga menjadi pertimbangan dalam penelitian ini berkaitan dengan response rate dari kuesioner yang didistribusikan pada responden, tingkat response rate dari 102 kuesioner yang disebar hanya 57 kuesioner yang kembali atau sebesar 55,88\% response rate. Hasil penilaian kuesioner yang kembali ternyata hanya 52 kuesioner atau sebesar 50,98\% yang layak diuji. Artinya bahwa terdapat 5 kuesioner yang tidak dapat diolah atau sebesar 4,90\% response error, sedangkan jumlah kuesioner yang tidak kembali berjumlah 45 atau $44,12 \%$. 


\section{Analisis Deskriptif}

\section{a. Kebijakan Treatment Karyawan}

Variabel ini terdiri dari tujuh item pernyataan.Berikut distribusi jawaban responden untuk variabel kebijakan treatment karyawan dan persentase kecenderungan skor jawaban.

\section{Tabel 1}

Sebaran Jawaban Responden Pada Variabel Kebijakan Treatment Karyawan (KTK)

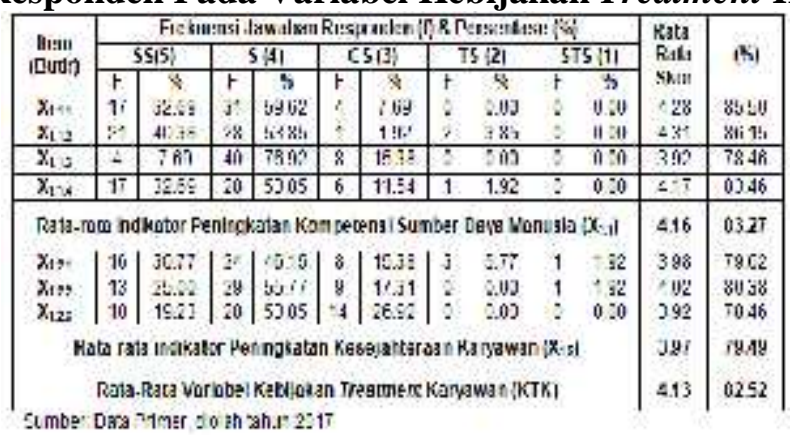

Tabel 1 menunjukkan bahwa variabel Kebijakan Treatment Karyawan (KTK) menurut tanggapan responden dikategorikan memiliki skor sangat tinggi. Kondisi ini terlihat dari nilai persepsi rerata responden sebesar 4,13 atau sebesar $(82,52 \%=$ sangat tinggi). Persepsi responden tersebut tampak bahwa secara keseluruhan persepsi responden terhadap variabel kebijakan treatment karyawan terlihat mengalami persentase yang tidak jauh berbeda untuk setiap indikator. Adapun presentase dari masing-masing indikator yang paling tinggi yaitu rata-rata indikator pada peningkatan kompetensi sumber daya manusia $\left(\mathrm{X}_{1.1}\right)$ dengan rata-rata skor 4,16 atau sebesar $83,27 \%$ dan rata-rata indikator pada peningkatan kesejahteraan karyawan $\left(\mathrm{X}_{1.2}\right)$ dengan rata-rata skor 3,97 atau sebesar 79,49\%. Kondisi ini berarti bahwa setiap pegawai/karyawan yang ditempatkan selalu mengutamakan kompetensi/keahlian yang dimiliki dan didukung oleh adanya pemberian kesejahteraan dari masing-masing SKPD yang ada pada Pemerintah Kota Baubau.

\section{b. Efektivitas Pengendalian Internal}

Efektivitas pengendalian internal sebagai variabel mediasi merupakan pengendalian kegiatan (operasional) organisasi yang dilakukan pimpinan untuk mencapai tujuan secara efisien, yang terdiri dari kebijakan-kebijakan dan prosedur-prosedur yang ditetapkan untuk mencapai tujuan tertentu dari operasi organisasi.Variabel ini mengacu pada komponen sistem pengendalian intern yang terdiri dari tiga belas item 
pernyataan [11]. Berikut distribusi jawaban responden untuk variabel efektivitas pengendalian intern dan persentase kecenderungan skor jawaban.

Tabel 2

Sebaran Jawaban Responden Pada Variabel Efektivitas Pengendalian Internal (EPI)

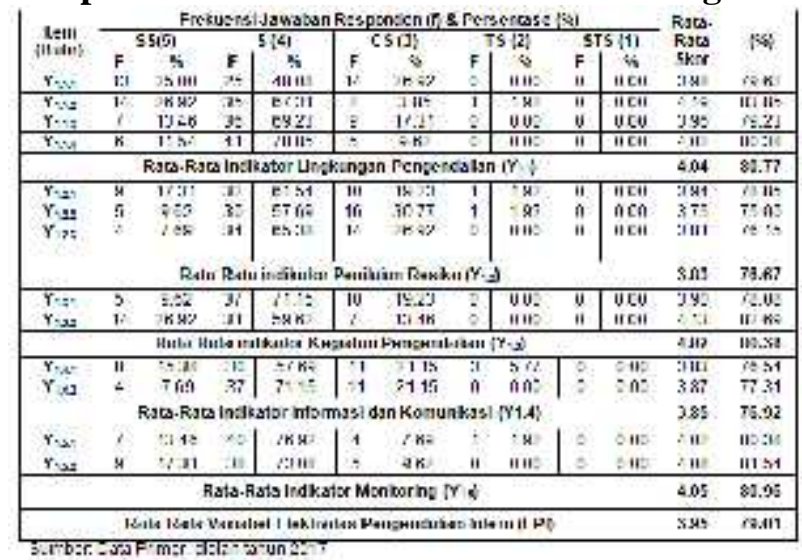

Tabel 2 menunjukkan bahwa variabel Efektivitas Pengendalian Internal (EPI) menurut tanggapan responden dikategorikan memiliki skor tinggi. Kondisi ini terlihat dari nilai persepsi rerata responden sebesar 3,95 atau sebesar $(79.01 \%=$ tinggi). Tampak bahwa secara keseluruhan persepsi responden terhadap variabel efektivitas pengendalian intern terlihat mengalami persentase yang tidak jauh berbeda untuk setiap indikator. Adapun presentase dari masing-masing indikator yang paling tinggi yaitu rata-rata indikator monitoring dengan rata-rata skor 4,05 atau sebesar $80,96 \%$, rata-rata indikator lingkungan pengendalian dengan rata-rata skor 4,04 atau sebesar $80,77 \%$, rata-rata indikator kegiatan pengendalian dengan rata-rata skor 4,02 atau sebesar $80,38 \%$, rata-rata indikator informasi dan komunikasi dengan rata-rata skor 3,85 atau sebesar $76,92 \%$, dan rata-rata indikator penilaian resiko dengan rata-rata skor 3,83 atau sebesar $76,67 \%$. Kondisi ini berarti bahwa efektivitas pengendalian intern dapat digambarkan dalam bentuk monitoring, lingkungan pengendalian, kegiatan pengendalian, informasi dan komunikasi yang dirancang dan bagaimana penilaian resiko yang diterapkan pada SKPD yang ada pada Pemerintah Kota Baubau.

\section{c. Kualitas Laporan Keuangan}

Indikator yang digunakan untuk mengukur kualitas laporan keuangan adalah karakteristik laporan keuangan yang terdiri dari relevan, andal, dapat dipahami, dan dapat dibandingkan, [8] serta diterjemahkan dalam sebelas item pernyataan. 
Variabel Kualitas Laporan Keuangan (KLK) menurut tanggapan responden dikategorikan memiliki skor tinggi. Kondisi ini terlihat dari nilai persepsi rerata responden sebesar 4,01 atau sebesar $(80,15 \%=$ tinggi). Secara keseluruhan persepsi responden terhadap variabel kualitas laporan keuangan terlihat mengalami persentase yang tidak jauh berbeda untuk setiap indikator. Adapun presentase dari masing-masing indikator yang paling tinggi yaitu rata-rata indikator andal dan dapat dibandingkan dengan rata-rata skor masing-masing 4,02 atau sebesar 80,38\%, ratarata indikator relevan dengan rata-rata skor 4,01 atau sebesar $80,23 \%$, dan rata-rata indikator dapat dipahami dengan rata-rata skor 4,01 atau sebesar $80,19 \%$. Kondisi ini berarti bahwa kualitas laporan keuangan dapat digambarkan dalam bentuk keandalan, daya banding, relevan dan dapat dipahaminya laporan keuangan yang disusun oleh SKPD yang ada pada Pemerintah Kota Baubau.Berikut distribusi jawaban responden untuk variabel kualitas laporan keuangan dan persentase kecenderungan skor jawaban adalah sebagai berikut.

Tabel 3

Sebaran Jawaban Responden Pada Variabel Kualitas Laporan Keuangan (KLK)

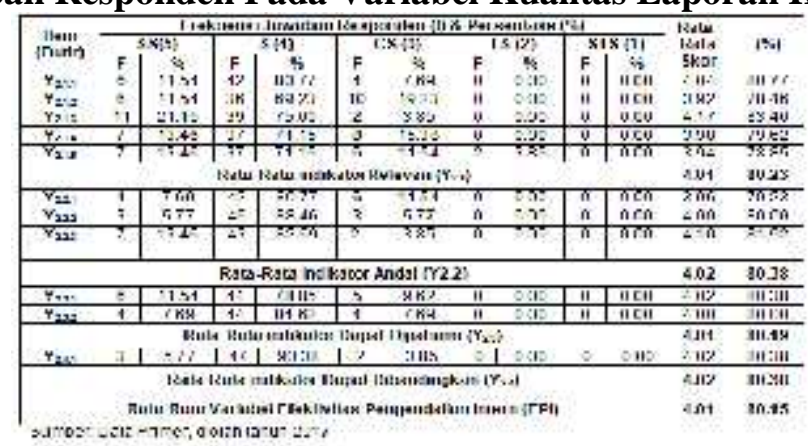

\section{Hasil Uji Validitas dan Reliabilitas Instrumen Penelitian}

Uji validitas menggunakan teknik pearson correlation dan uji reliabilitas menggunakan teknik cronbach alpha. Hasil pengujian validitas menunjukkan bahwa hanya dua variabel yang memiliki koefisien validitas $>0.05$ sehingga dinyatakan tidak valid, yaitu variabel kebijakan treatment karyawan dengan item pernyataan $\mathrm{X}_{1.1 .5}$ dan variabel efektivitas pengendalian internal dengan item pernyataan $\mathrm{Y}_{1.3 .2}$ dan $\mathrm{Y}_{1.4 .2}$. Item pernyataan yang tidak valid dalam penelitian ini dikeluarkan dari kuesioner. Hasil uji realibilitas dari ketiga variabel yang diteliti dalam penelitian ini menunjukan bahwa ketiga variabel tersebut memiliki koefisien reliabilitas $>0.6$ sehingga instrumen penelitian dinyatakan reliabel. 


\section{Hasil Pengujian Asumsi Klasik}

Pengujian asumsi klasik dalam penelitian ini dilakukan untuk memenuhi kriteria BLUE (Best Linier Unbias Estimate).Hal ini disebabkan oleh penggunaan analisis jalur. Berikut adalah hasil pengujian uji asumsi klasik.

\section{a. Asumsi Normalitas}

Pengujian asumsi klasik normalitasmenggunakan grafik normal probability plot dengan kriteria model regresi memenuhi asumsi normalitas jika data menyebar di sekitar garis diagonal.

\section{Grafik 1}

\section{Hasil Pengujian Asumsi Normalitas Model Persamaan 1}

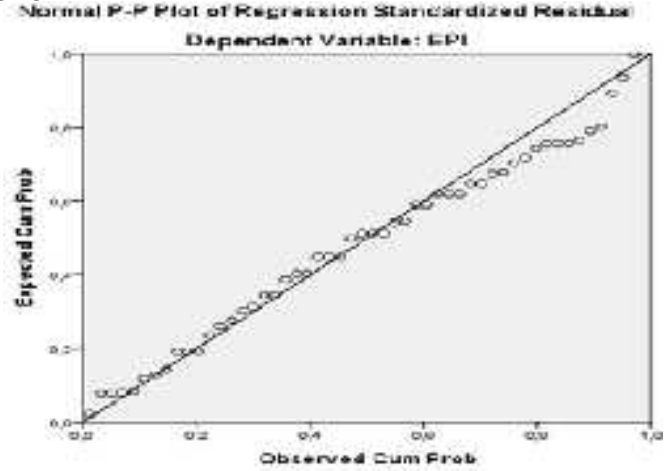

Grafik 1 menunjukan data menyebar di sekitar garis diagonal dan mengikuti arah diagonal, sehingga dapat disimpulkan bahwa model persamaan 1 telah memenuhi asumsi normalitas. Hasil pengujian Kolmogorov Smirnov menunjukan nilai asymp. Sig (2-tailed) sebesar 0.456 , atau lebih besar dari 0.05 sehingga model persamaan 1 dinyatakan telah memenuhi asumsi normalitas.

\section{Grafik 2}

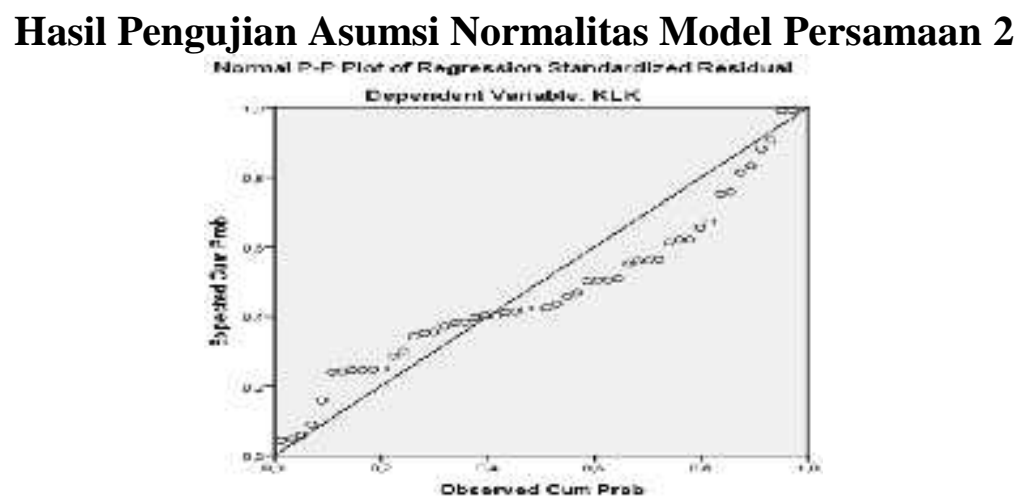

Grafik 2 menunjukan data penelitian menyebar di sekitar garis diagonal dan mengikuti arah garis diagonal, sehingga dapat disimpulkan bahwa model persamaan 2 telah memenuhi asumsi normalitas. Hasil pengujian Kolmogorov Smirnov 
menunjukan nilai asymp. Sig (2-tailed) sebesar 0.115, atau lebih besar dari 0.05 sehingga model persamaan 2 dinyatakan telah memenuhi asumsi normalitas.

\section{b. Asumsi Multikolinieritas}

Asumsi multikolinieritas hanya dilakukan pada model persamaan 2. Hal ini disebabkan penggunakan variabel eksogen dalam model persamaan 1 hanya berjumlah satu yaitu kebijakan treatment karyawan. Sedangkan pada model persamaan 2, variabel eksogen yang digunakan berjumlah dua yaitu kebijakan treatment karyawan dan efektivitas pengendalian internal.Kriteria pengujian multikolinieritas menggunakan nilai VIF $<10$ dan tolerance $>0.1$. Berikut adalah hasil uji asumsi multikolineritas pada model persamaan 2.

\section{Tabel 4}

\begin{tabular}{|c|c|c|c|c|}
\hline Hasil Uji & Asums & Multik & inme & as nodel Persa \\
\hline No. & Variabel & Tolerance & VIF & Keterangan \\
\hline 1 & KTK & 0.818 & 1088 & Trask tsyani m.tikclinistns \\
\hline 2 & $L^{\top}$ & 0.919 & 1.098 & 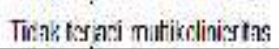 \\
\hline
\end{tabular}

Sumber: DataPirce Diobn 2017

Hasil uji asumsi multikolinieritas menunjukan bahwa variabel kebijakan treatment karyawan dan efektivitas pengendalian internal memiliki nilai tolerance > 0.10 dan nilai VIF $<10$, sehingga model persamaan 2 yang diajukan dalam penelitian ini tidak mengalami gejala multikolinieritas atau telah memenuhi asumsi multikolinieritas.

\section{c. Asumsi Heterokedastisitas}

Uji heteroskedastisitas menggunakan grafik Scatterplot.Kriteria tidak terjadi gejala heteroskedastisitas adalah titik-titik yang terdapat pada grafik tidak membentuk pola tertentu yang jelas dan menyebar diatas dan dibawah angka nol pada sumbu Y. Berikut adalah hasil uji asumsi heteroskedastisitas model persamaan 2.

\section{Grafik 3}

\section{Hasil Uji Asumsi Heteroskedastisitas Model Persamaan 2}

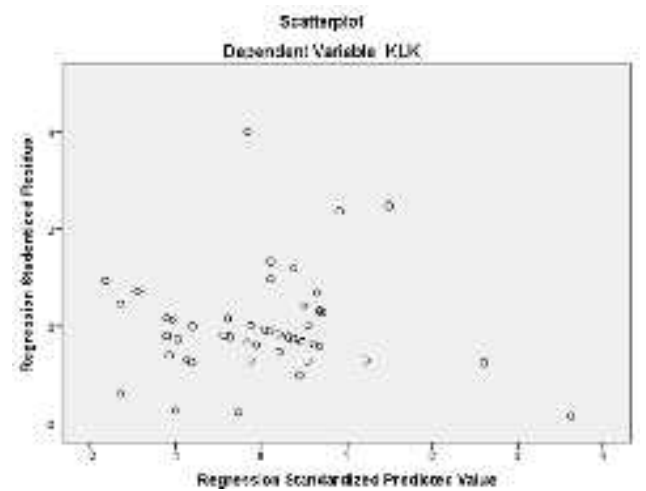


Grafik 3 menunjukan data dalam penelitian ini menyebar secara tidak beraturan dan tidak membentuk pola yang jelas, sehingga dapat disimpulkan bahwa model persamaan 2 telah memenuhi asumsi heteroskedastisitas.

\section{Hasil Analisis Jalur}

Analisis jalur dilakukan setelah ketiga asumsi klasik terpenuhi. Penelitian ini menggunakan analisis jalur dengan dua model persamaan jalur, yakni:

$$
\begin{aligned}
& \text { I }: Z_{\mathrm{EPI}}=\alpha_{0}+\alpha_{1} \mathrm{KTK}+1 \\
& \text { II }: \mathrm{Z}_{\mathrm{KLK}}=\mathrm{Y}_{0}+\mathrm{Y}_{1} \mathrm{Z}_{\mathrm{KTK}}+\mathrm{Y}_{2} \mathrm{Z}_{\mathrm{EPI}}+{ }_{2}
\end{aligned}
$$

\section{a. Hasil Analisis Model Persamaan 1}

\section{Tabel 5}

\begin{tabular}{|c|c|c|c|c|}
\hline & Kowision & thitung & Fvaluo & Kotorangyan \\
\hline Konsterng & 3.014 & & & \\
\hline XTK & 3.264 & 2065 & 0.641 & Sizrifiken \\
\hline
\end{tabular}

Hasil Analisis Model Persamaan 1

Model persamaan 1 berdasarkan tabel 5, dapat dirumuskan sebagai berikut.

$$
\mathrm{Z}_{\mathrm{EPI}}=0.284 \mathrm{Z}_{\mathrm{KTK}}
$$

Model persamaan 1 di atas menunjukan bahwa jika tidak ada kebijakan treatment karyawan, maka penerapan efektivitas pengendalian internal adalah sebesar 3.014. Koefisien jalur KTK menunjukan nilai sebesar 0.284, artinya jika kebijakan treatment karyawan ditingkatkan satu skor, maka efektivitas pengendalian internal akan meningkat sebesar 0.284.

1) Koefisien Determinasi

Koefisien determinasi pada model persamaan 1 digunakan untuk menghitung besarnya pengaruh kebijakan treatment karyawan terhadap efektivitas pengendalian internal. Nilai koefisien determinasi yang diperoleh dari model persamaan 1 adalah sebesar 0.081 . Hasil ini mengindikasikan bahwa $8.1 \%$ variasi dari efektivitas pengendalian internal dapat dijelaskan oleh kebijakan treatment karyawan. Koefisien determinasi tersebut juga menunjukan bahwa $8.1 \%$ keberhasilan penerapan efektivitas pengendalian internal dipengaruhi oleh kebijakan treatment karyawan, sedangkan 91.9\% dipengaruhi oleh variabel yang tidak diteliti dalam model persamaan ini.

2) Hasil Uji Statistik t

Uji statistik $\mathrm{t}$ dalam model persamaan 1 digunakan untuk menguji hipotesis pertama, yaitu pengaruh kebijakan treatment karyawan terhadap efektivitas 
pengendalian internal. Hasil pengujian menunjukan bahwa koefisien jalur kebijakan treatment karyawan adalah sebesar 0.284 dan nilai $t_{\text {hitung }}$ sebesar 2.095 dengan tingkat probabilitas 0.041. Hasil ini mengindikasikan bahwa hipotesis pertama diterima.

\section{b. Hasil Analisis Model Persamaan 2}

Tabel 6

Hasil Analisis Model Persamaan 2

\begin{tabular}{|c|c|c|c|c|}
\hline & Koefisien & thitung & p-value & Keterangan \\
\hline Konsterta & 2311 & & & \\
\hline KTK & $.6,64$ & 0.312 & 0.756 & Thak Sigrifikan \\
\hline [ता & 0.17 & 364 & D.001 & Syrohkan \\
\hline
\end{tabular}

Model persamaan 2 berdasarkan tabel di atas, dapat dirumuskan sebagai berikut.

$$
Z_{\mathrm{KLK}}=-0.041 \mathrm{Z}_{\mathrm{KTK}}+0.477 \mathrm{Z}_{\mathrm{EPI}}
$$

Model persamaan 2 di atas menunjukan bahwa jika tidak ada kebijakan treatment karyawan dan efektivitas pengendalian internal, maka kualitas laporan keuangan adalah sebesar 2.311. Koefisien jalur KTK menunjukan nilai -0.041, artinya setiap peningkatan satu skor KTK akan mengurangi kualitas laporan keuangan sebesar 0.041. Koefisien jalur efektivitas pengendalian internal menunjukan nilai sebesar 0.477 dengan interpretasi setiap peningkatan satu skor efektivitas pengendalian internal maka akan meningkatkan kualitas laporan keuangan sebesar 0.477 .

1) Koefisien Determinasi

Koefisien determinasi pada model persamaan 2 digunakan untuk menghitung besarnya pengaruh kebijakan treatment karyawan dan efektivitas pengendalian internal terhadap kualitas laporan keuangan. Nilai koefisien determinasi yang diperoleh dari model persamaan 2 adalah sebesar 0.218. Hasil ini mengindikasikan bahwa 21.8\% variasi dari kualitas laporan keuangan dapat dijelaskan oleh kebijakan treatment karyawan dan efektivitas pengendalian internal. Koefisien determinasi tersebut juga menunjukan bahwa 21.8\% keberhasilan kualitas laporan keuangan dipengaruhi oleh kebijakan treatment karyawan dan efektivitas pengendalian internal, sedangkan $78.2 \%$ dipengaruhi oleh variabel lain yang tidak diteliti dalam penelitian ini.

2) Hasil Uji Statistik t 
Uji statistik t dalam model persamaan 2 digunakan untuk menguji hipotesis 2 dan hipotesis 3. Berikut adalah penjelasannya.

(a) Hipotesis Kedua

Hipotesis kedua adalah kebijakan treatment karyawan berpengaruh terhadap kualitas laporan keuangan. Hasil pengujian menunjukan bahwa koefisien kebijakan treatment karyawan adalah sebesar -0.041 dan $t_{\text {hitung }}$ sebesar -0.312 dengan tingkat probabilitas sebesar 0.756 . Tingkat probabilitas $t_{\text {hitung }}$ yaitu sebesar $0.756>0.05$ sehingga dapat disimpullkan bahwa hipotesis kedua ditolak, artinya kebijakan treatment karyawan tidak berpengaruh terhadap kualitas laporan keuangan.

(b) Hipotesis Ketiga

Hipotesis ketiga adalah pengaruh kebijakan treatment karyawan terhadap kualitas laporan keuangan dimediasi oleh efektivitas pengendalian internal. Syarat tercapainya efek mediasi adalah (1) variabel eksogen harussignifikan dalam memengaruhi variabel mediasi;(2) variabel eksogen harus signifikan dalam memengaruhi variabel endogen; dan (3) variabel mediator harus signifikan memengaruhi variabel endogen. Berdasarkan kriteria tersebut, maka persyaratan pertama dan ketiga telah terpenuhi, akan tetapi persyaratan kedua tidak terpenuhi, yaitu variabel kebijakan treatment karyawan tidak berpengaruh terhadap kualitas laporan keuangan. Dengan demikian, hipotesis ketiga ditolak, artinya efektivitas pengendalian internal tidak memediasi pengaruh kebijakan treatment terhadap kualitas laporan keuangan.

\section{c. Validitas Model}

Total keragaman data yang dapat dijelaskan oleh model diukur dengan:

$$
\begin{aligned}
\mathrm{R}_{\mathrm{m}}^{2} & =1-\mathrm{P}_{\mathrm{e} 1}^{2} \mathrm{P}_{\mathrm{e} 2}^{2} \\
\mathrm{e}_{1} & =\sqrt{ }(1-0.081)=0.959 \\
\mathrm{e}_{2} & =\sqrt{ }(1-0.218)=0.884 \\
\mathrm{R}_{\mathrm{m}}^{2} & =1-(0.959)^{2}(0.884)^{2} \\
& =0.281
\end{aligned}
$$

Keragaman data yang dapat dijelaskan oleh model adalah sebesar 28.1\%. Hal ini dapat diinterpretasikan bahwa model hasil analisis dapat menjelaskan sebesar $28.1 \%$ 
terhadap fenomena yang dikaji, sedangkan sisanya sebesar $71.9 \%$ dijelaskan oleh variabel lain yang tidak dikaji dalam penelitian ini.

\section{Pembahasan}

Hasil pengujian hipotesis menunjukkan bahwa terdapat dua hipotesis dinyatakan diterima dan satu hipotesis dinyatakan ditolak. Selain itu, hasil analisis jalur pada variabel intervening yakni efektivitas pengendalian internal menunjukkan adanya efek mediasi penuh (full mediating).Berikut ini uraian pembahasan dari masing-masing hipotesis tersebut.

\section{a. Pengaruh Kebijakan Treatment Karyawan Terhadap Efektivitas Pengendalian Internal}

Hipotesis pertama menyatakan kebijakan treatment karyawan berpengaruh terhadap efektivitas pengendalian intern.Hasil analisis regresi menunjukkan bahwa kebijakan treatment karyawan berpengaruh positif dan signifikan terhadap efektivitas pengendalian internal.Hal ini menunjukkan kebijakan treatment karyawan yang diukur melalui peningkatan kompetensi SDM dan peningkatan kesejahteraan karyawan /pegawai memiliki pengaruh yang signifikan terhadap efektivitas pengendalian internal sektor publik.

Hasil uji hipotesis terpenuhi disebabkan pegawai/karyawan yang ditempatkan sebagai penatausahaan keuangan pada masing-masing SKPD yang berada pada lingkup Pemerintah Daerah Kota Baubau menjalankan tugasnya sesuai dengan basis pendidikan dan keahlian yang dimiliki.Kondisi ini menegaskan adanya kontrol yang ketat terhadap perekrutan dan penempatan sumber daya manusia (pegawai /karyawan) sehingga membentuk sebuah kebijakan dasar yang mendukung tercapainya visi dan misi pemerintah daerah tersebut.Selain itu, pemerintah daerah selaku pihak yang memiliki otoritas penuh terhadap masing-masing SKPD ikut mendorong efektivitas pengendalian internal melalui treatment pegawai/karyawan yang telah dilakukan, yakni berupa penggantian biaya maupun hororarium atas tugas tambahan yang diberikan.Treatment ini diberikan sebagai upaya pemerintah daerah dalam mengontrol sistem pengendalian internal pada masing-masing pegawai/karyawan. 


\section{b. Pengaruh Kebijakan Treatment Karyawan Terhadap Kualitas Laporan Keuangan}

Hipotesis kedua menyatakan kebijakan treatment karyawan berpengaruh terhadap kualitas laporan keuangan.Hasil analisis regresi menunjukkan kebijakan treatment karyawan tidak berpengaruh terhadap kualitas laporan keuangan sehingga hipotesis kedua ditolak.Hal ini menunjukkan bahwa kebijakan treatment karyawan yang diukur melalui peningkatan kompetensi SDM dan peningkatan kesejahteraan karyawan /pegawai tidak memiliki pengaruh yang signifikan terhadap kualitas laporan keuangan sektor publik.

Hasil uji hipotesis tidak terpenuhi disebabkan sebagian responden memandang bahwa treatment yang diberikan terhadap pegawai penatausahaan keuangan tidak sejalan dengan kinerja yang diharapkan sehingga berdampak pada kualitas laporan keuangan yang dihasilkan.Kondisi ini dipandang bahwa treatment yang diberikan pemerintah daerah belum dapat memaksimalkan kinerja pegawai /karyawan dalam menghasilkan kualitas laporan keuangan yang memadai dan upaya peningkatan kesejahteraanpegawai/karyawan diluar penghasilan pokok.

c. Pengaruh Kebijakan Treatment terhadap Kualitas Laporan Keuangan Dimediasi oleh Efektivitas Pengendalian Internal

Hasil penelitian menunjukan kebijakan treatment karyawan berpengaruh positif terhadap efektivitas pengendalian internal, efektivitas pengendalian internal berpengaruh positif terhadap kualitas laporan keuangan, sedangkan kebijakan treatment karyawan tidak berpengaruh terhadap kualitas laporan keuangan. Dengan demikian, hasil pengujian hipotesis menunjukanefektivitas pengendalian internal memediasi pengaruh kebijakan treatment karyawan terhadap kualitas laporan keuangan.

Kompetensi SDM merupakan salah satu kebijakan treatment yang digunakan pemerintah untuk meningkatkan kemampuan SDM melalui keikutsertaan dalam berbagai pelatihan maupun bimbingan teknis pengelolaan keuangan daerah. Kebijakan treatment dalam penelitian ini juga diukur melalui peningkatan kesejahteraan SDM guna memotivasi SDM dalam meningkatkan kinerjanya. Adapun tingkat pelaksanaan kebijakan treatment karyawan pada Pemerintah Kota Baubau adalah sebesar $82.52 \%$, atau memiliki tingkat penerapan yang sangat tinggi. 
Tingginya tingkat pelaksanaan kebijakan treatment karyawan pada Pemerintah Kota Baubau justru tidak berpengaruh terhadap kualitas laporan keuangan, yakni sebesar $80.15 \%$. Sedangkan tingkat pengendalian internal yang diterapkan adalah sebesar $79.01 \%$, artinya pengendalian internal yang diterapkan Pemerintah Kota Baubau telah dilaksanakan dengan baik. Dengan adanya efektivitas pengendalian internal Pada Pemerintah Kota Baubau, maka kebijakan treatment karyawan dapat berpengaruh terhadap kualitas laporan keuangan. Oleh karena itu, efektivitas pengendalian internal merupakan faktor yang sangat penting sebagai variabel intervening, sebab tanpa adanya efektivitas pengendalian internal pada Pemerintah Kota Baubau maka kebijakan treatment karyawan tidak akan berpengaruh terhadap kualitas laporan keuangan.

\section{KESIMPULAN}

Berdasarkan analisis data yang dilakukan, maka diperoleh kesimpulan sebagai berikut: Kebijakan treatment karyawan berpengaruh positif terhadap efektivitas pengandalian internal Pemerintah Kota Baubau, artinya semakin tinggi tingkat pelaksanaan kebijakan treatment karyawan, maka efektivitas pengendalian internal juga semakin meningkat. Kebijakan treatment karyawan tidak berpengaruh terhadap kualitas laporan keuangan Pemerintah Kota Baubau, artinya peningkatan pelaksanaan kebijakan treatment karyawan tidak akan mengakibatkan peningkatan kualitas laporan keuangan. Pengaruh kebijakan treatment karyawan terhadap kualitas laporan keuangan dimediasi oleh efektivitas pengendalian internal, artinya dengan adanya efektivitas pengendalian internal, maka kebijakan treatment karyawan dapat berpengaruh secara tidak langsung terhadap kualitas laporan keuangan.

\section{SARAN}

Beberapa hal yang disarankan peneliti untuk penelitian selanjutnya adalah sebagai berikut: Objek penelitian dapat diperluas untuk seluruh pemerintah daerah se-Sulawesi Tenggara sehingga dapat meningkatkan daya generalisasi. Fokus penelitian di bidang kebijakan treatment karyawan khususnya pada indikator peningkatan kesejahteraan karyawan masih sangat jarang diteliti dalam sektor publik, sehingga penelitian ini diharapkan dapat menarik minat bagi peneliti selanjutnya untuk mengkaji hal tersebut. 


\section{DAFTAR PUSTAKA}

[1] KPMG. 2012. International Survey of Corporate Responsibility Reporting. Forensic: Integrity Survey 2012.

[2] http://www.kompasiana.com/2013/5/sikowiyanto/kritik-atas-sistem-pengendalianinternal-pemerintah.html. Diakses September 2017.

[3] Artana, Purdanti, dan Meitriana. 2014. Pengaruh Tingkat Pendidikan Karyawan Terhadap Kualitas Sistem Pengendalian Intern Pada Koperasi Serba Usaha.EJournal Universitas Pendidikan Ganesha, Jurusan Pendidikan Ekonomi, Vol. 4(1), pp.10-23.

[4] Ashbaugh-Skife, et.al. 2007. The Discovery and Reporting of Internal Control Deficiencies Prior to SOX-Mandated Audits. McCombs Research. Paper Series No.ACC-02-05, pp.1-32.

[5] Doyle, et, al. 2007. Determinants of Weaknesses in Internal Control Over Financial Reporting. Journal of Accounting and Economics, Vol. 44, pp.193-223.

[6] Sultana dan Haque. 2011. Evaluation of Internal Control Structure: Evidence from Six Listed Banks in Bangladesh. ASA University Review.January-June, 2011, Vol. 5(1), pp.69-81.

[7] Ge, and McVay. 2005. The Disclosure of Material Weaknesses in Internal Control After the Sarbanes-Oxley Act. Accounting Horizon, Vol. 19(3), pp.137-158.

[8] Peraturan Pemerintah Nomor 71 Tahun 2010 tentang Standar Akuntansi Pemerintahan.

[9] Sekaran, Uma. 2011. Research Methods for Business: A Skill-Building Approach. Forth Edition.Salemba Empat; Jakarta.

[10] Sugiyono.2008. Metode Penelitian Kuantitatif, Kualitatif dan $R \&$ D. Bandung: Penerbit Alfabeta.

[11] Committee of Sponsoring Organization of The Treadway Commission (COSO). 1994. Internal Control Integrated Framework. New York: AICPA Publication. 